\title{
The Role of Job Satisfaction, Work-life Balance on the Job Performance of Female Nurses at Local General Hospital
}

\author{
Putu Deva Govinda Krisna Wijaya and I. Gusti Made Suwandana
}

\section{ABSTRACT}

\begin{abstract}
This study aims to analyze the effect of Job Satisfaction, Work-Life Balance on the Job Performance of Female Nurses at Klungkung General Hospital. The sample in this study were all female nurses totaling 206 female nurses at the Klungkung General Hospital. Filling out the questionnaire was done using a google form due to the Covid-19 pandemic and it was more effective and efficient. Determination of the sample in this study is using nonprobability sampling technique with saturated sampling, namely the technique of determining the sample when all members of the population are used as samples. The saturated sample can also be referred to as a census because all members of the female nurse population are sampled. Data were analyzed using Path Analysis on SPSS Program. The results show that Work-life balance has a positive and significant effect on the performance of female nurses; Work-life balance has a positive and significant effect on job satisfaction of female nurses; Job satisfaction has a positive and significant effect on nurse performance; and job satisfaction significantly mediate the relationship between the work-life balance on the performance of female nurses.
\end{abstract}

Keywords: Job Satisfaction, Job Performance, Work-Life Balance.
Submitted : January 14, 2022

Published : February 13, 2022

ISSN: $2507-1076$

DOI: $10.24018 /$ ejbmr.2022.7.1.1268

Putu Deva Govinda Krisna Wijaya

Faculty of Economy and Business, Udayana University, Bali, Indonesia.

(e-mail: devagovindaejbmr@gmail.com) I. Gusti Made Suwandana

Faculty of Economy and Business, Udayana University, Bali, Indonesia.

*Corresponding Author

\section{INTRODUCTION}

As time goes by, the role of women is currently needed in various jobs. Previously, women were considered less capable and could only depend on men, with the movement of women doing things outside of the stigma, women's confidence in doing everything increased. At this time gender is not an obstacle or a problem to carry out a career. Female nurses and doctors are an example of gender equality in health workers.

Human Resources are assets that must be maintained so that a qualified workforce in an agency. The company cannot be separated from the human workforce, even though it has supporting facilities and infrastructure and even has advanced technological tools, if there is no human workforce, the company cannot achieve its target. In this study, female nurses were selected because there were problems regarding performance variables, work-life balance, and job satisfaction and the existence of multiple roles (working and being a housewife) that women needed to deal with. When there is a problem, women find it more difficult to control their mood at work (Darma \& Supriyanto, 2017).

Nurses really need to pay attention to performance, in order to be able to provide maximum service to patients. However, to be able to improve their performance and even the quality of their work, they need training if needed. The success of the service is largely determined by the results of the nurse's performance at work, performance is a work success both in terms of quantity and quality in carrying out their duties and responsibilities. Performance is the result of the quality and quantity of work and time achieved by female nurses. Seeing the current situation where the number of patients continues to increase, of course, the roles, duties and responsibilities of female nurses are increasing than usual, and the demands on the performance of nurses will be highly evaluated (Martono et al., 2018).

If female nurses already have families, they are required to be maximal at work and outside of work, thereby increasing the work and responsibilities they carry. So female nurses need to pay attention to work flexibility in carrying out their work, family, and social life (Johari et al., 2018). Work-life balance is needed to achieve a balance between work and personal life, but this application requires support from the work environment (Saragih, 2021). Work-life balance is an individual's ability to balance the demands of work and personal and family needs (Ranjan \& Khatke, 2021). In general, a low work-life balance can affect the sustainability of the performance of female nurses, which will result in the division of concentration and time when working. To maximize work-life balance and produce a good performance, a female nurse needs to have a high sense of job satisfaction.

In this case, job satisfaction related to female nurses must be increased as much as possible so that the discipline, loyalty, and dedication of female nurses can increase. The more satisfied female nurses are with the work they do, the higher their performance level (Juliarti et al., 2018). Usually a female nurse achieves job satisfaction if the desired target has been achieved, and there is no gap between expectations and reality (Pawirosumarto et al., 2017) and the level of 
satisfaction of female nurses is appreciated if it is in accordance with various aspects of work in the situation at work (Usman et al., 2019). Job satisfaction is a positive feeling towards the work that has been done, adjustment and working conditions, with this in accordance with the expectations of female nurses. So that a female nurse can enjoy her work and can be rewarded for doing it well (Kuranga et al., 2020)

The object of this study was conducted at the Klungkung General Hospital. Based on the initial interview with the Head of the Nursing Department at the Klungkung General Hospital to measure performance, it can be seen from the achievements produced by nurses in the Employee Performance Targets. Currently, nurses who have achievements have not received special rewards, only given in the form of service incentives. Then the Covid-19 pandemic and the emergence of a new variant of the virus made female nurses at the hospital overwhelmed because the quantity faced was increasing and there was fear because they worked in places that were in direct contact with patients. It also made the performance of nurses in hospitals decrease due to the implementation of their duties that were carried out half-heartedly. There are also some nurses who are less disciplined in working time such as being late for work. In addition, there are also complaints of female nurses who have toddlers while working the night shift because they have to take care of their children at home. Some of them also find it difficult to allocate time for children at home who do online learning which requires the role of parents in teaching their children.

Furthermore, an initial pre-survey was carried out on 15 female nurses, with the aim of being able to find out how the current condition or situation happened to the performance of female nurses at the Klungkung General Hospital. From the survey, it was found that nurses still do not focus on work, so the quality and quantity of their work can decrease and the number of jobs makes female nurses overwhelmed and their performance decreases. So that there is still a low performance in the Klungkung General Hospital. Then there is a work-life balance that has not been achieved and they feel that the income they get is still lacking which causes low job satisfaction

There are several research gaps in previous research. Puspitasari \& Darwin (2021) states that work-life balance has a positive and significant effect on employee performance. However, Saifullah (2020) found that there was no significant effect between the work-life balance on the performance of Muslim female employees. Rafsanjani et al. (2019) state that job satisfaction has a significant and positive effect on employee performance. However, Wulandari \& Hadi (2021) stated that job satisfaction had no effect on employee performance at nurses. Mendis \& Weerakkody (2017) stated that there is a positive influence between the work-life balance in increasing employee performance through employee job satisfaction. However, Wulandari \& Hadi (2021) states that job satisfaction as an intervening variable does not mediate the relationship between work-life balance and employee performance.

\section{LITERATURE REVIEW}

\section{A. Homeostasis Theory}

This theory was first proposed by Heider in 1932. The theory of homeostasis is a form of human behavior that wants to find balance within itself. This theory is used as a foothold for the role of work-life balance in a company. If a person's desires are fulfilled in balancing his work with his personal life, therefore a person can minimize the stress that occurs to them (Herlambang \& Murniningsih, 2019). Homeostasis theory focuses on the emotional balance and mental health of a person. This process is obtained from life experiences and interactions with other people and is influenced by norms and culture. During this process, humans not only make adjustments but also humans interact with the environment, to maintain their survival. If there is an unbalanced relationship, then the homeostatic theory can improve the balance in communications between individuals.

\section{B. Attribution Theory}

This theory was first proposed by Fritz Heider in 1958. According to Herlambang \& Murniningsih (2019), Attribution theory is to recognize how a person interprets an event, the reasons, and causes of his behavior. This relationship can be related to performance, that the results of performance are things that cannot be separated from the survival of the agency or company. With nurses, not all can improve their performance if done in the same way, because each person has different characteristics and behaviors.

\section{Research Hypothesis}

Work-life balance is a balance between work and personal life that is owned by a female nurse. With this, someone who can control the balance at work and personal life can improve their performance while working. Quoted from Puspitasari \& Darwin (2021), "work-life balance has a positive effect on employee performance which occurs through joint efforts between employees and employers, work-life balance affects employee performance because harmony between personal life and work is an important need for every employee that can affect mood, the focus of thoughts, and actions at work, therefore the higher employee satisfaction with work-life balance, the higher the quality. employee performance."

\section{H1: Work-Life Balance has a positive effect on the performance}

Work-life balance is an effort made by an individual in living his life, both work, and personal life. With this, someone who can maintain this balance can produce satisfaction at work. Junaidin et al. (2019), found that worklife balance has a positive effect on job satisfaction. Where the better the work-life balance felt by employees, the better job satisfaction will be. While other research has a positive effect on work-life balance, this indicates that the higher the application of work-life balance, the higher the satisfaction (Herlambang \& Murniningsih, 2019)

H2: Work-Life Balance has a positive effect on Job Satisfaction 
Job satisfaction is a positive attitude contained in a female nurse when she is comfortable at work and likes the job. With this, someone who has a positive attitude towards his work and likes his job can improve his performance. This statement can be supported by previous research conducted by Suwandana \& Perdanawati (2020) that there is a significant influence between job satisfaction on employee performance. Sambung (2019), also found the same positive effect between the variables of job satisfaction and work discipline on the performance of bank employees.

\section{H3: Job Satisfaction has a positive effect on Performance}

A female nurse who has a good work-life balance when dividing her time between work and her personal life, it is certain that the female nurse has satisfaction while working so that the performance of the female nurse will increase as well. This statement can be supported by previous research conducted by Herlambang \& Murniningsih (2019) that there is job satisfaction mediating the relationship between worklife balance and employee performance. Mendis \& Weerakkody (2017) stated there is a positive influence between the work-life balance in increasing employee performance through employee job satisfaction. So, the better the WLB of the employee, the better the employee performance and employee job satisfaction.

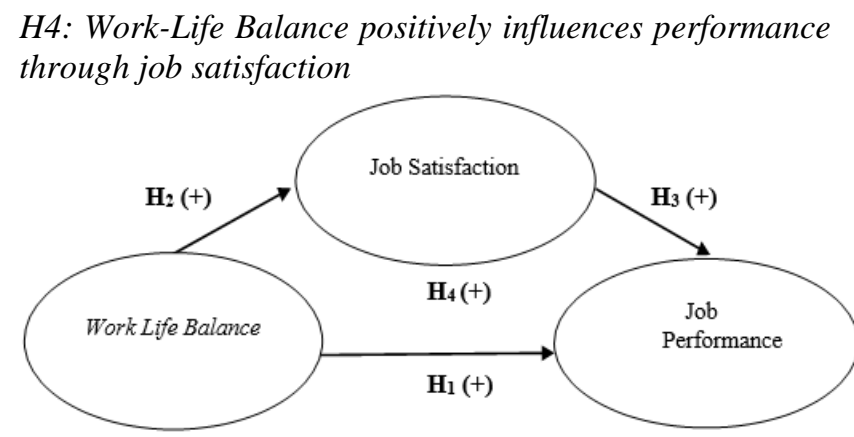

Fig. 1. Conceptual Framework.

\section{Methodology}

The sample in this study were all female nurses totaling 206 female nurses at the Klungkung General Hospital. Filling out the questionnaire was done using a google form due to the Covid-19 pandemic and it was more effective and efficient. Determination of the sample in this study is using nonprobability sampling technique with saturated sampling, namely the technique of determining the sample when all members of the population are used as samples. The saturated sample can also be referred to as a census because all members of the female nurse population are sampled.

\section{RESUlTS AND DisCUSSION}

The work-life balance variable has a coefficient of 0.983 which means that work-life balance has a positive influence on the job satisfaction of female nurses. It can also mean that if the work-life balance increases by one unit, the job satisfaction of female nurses will increase by 0.983 or 98.3 percent. The work-life balance variable has a coefficient of
0.599 which means that work-life balance has a positive influence on the performance of female nurses. It can also mean that if the work-life balance increases by one unit, the performance of female nurses will increase by 0.599 or 59.9 percent. The job satisfaction variable has a coefficient of 0.458 which means job satisfaction has a positive influence on the performance of female nurses. It can also mean that if job satisfaction increases by one unit, the performance of female nurses will increase by 0.458 or 45.8 percent

\begin{tabular}{|c|c|c|c|c|c|}
\hline \multicolumn{6}{|c|}{ Substructure 1} \\
\hline & \multirow{2}{*}{ B } & \multirow{2}{*}{$\begin{array}{c}\text { Std } \\
\text { Error }\end{array}$} & \multirow{2}{*}{ Beta } & \multicolumn{2}{|c|}{ t value } \\
\hline & & & & $t_{\text {count }}$ & Sig. \\
\hline (Constant) & 3.729 & 0.476 & & 7.831 & 0.000 \\
\hline $\begin{array}{l}\text { Work life } \\
\text { balance }\end{array}$ & 1.142 & 0.115 & 0.983 & 76.408 & 0.000 \\
\hline R Square & \multirow{2}{*}{\multicolumn{5}{|c|}{$\begin{array}{c}0.966 \\
0.000\end{array}$}} \\
\hline F Sig. & & & & & \\
\hline \multicolumn{6}{|c|}{ Substructure 2} \\
\hline & \multirow{2}{*}{ B } & Std & \multirow{2}{*}{ Beta } & \multicolumn{2}{|c|}{$\mathrm{t}$ value } \\
\hline & & Error & & $t_{\text {count }}$ & Sig \\
\hline (Constant) & 14.779 & 1.469 & & 10.058 & 0.000 \\
\hline $\begin{array}{l}\text { Work life } \\
\text { balance }\end{array}$ & 1.383 & 0.220 & 0.599 & 6.287 & 0.000 \\
\hline Job satisfaction & 0.682 & 0.189 & 0.458 & 8.877 & 0.000 \\
\hline R Square & & & 0.557 & & \\
\hline F Sig. & & & 0.000 & & \\
\hline
\end{tabular}

Calculating the standard error and the coefficient of total determination:

$$
\begin{aligned}
& P e i=\sqrt{1-R^{2}}=\sqrt{1-0.966}=0.184 \\
& P e i=\sqrt{1-R^{2}}=\sqrt{1-0.557}=0.665
\end{aligned}
$$

Based on the calculation of the standard error value, the results obtained are e 1 or standard error model I of 0.184 and e2 or standard error of model II of 0.665 . The calculation of the coefficient of total determination is as follows:

$$
\mathrm{R}^{2} \mathrm{~m}=1-\left(\mathrm{e}_{1}\right)^{2}\left(\mathrm{e}_{2}\right)^{2}=1-(0,184)^{2}(0,665)^{2}=0,985
$$

The total coefficient of determination of 0.985 means that 98.5 percent of the variation in performance is influenced by work-life balance and job satisfaction, while the remaining 1.5 percent is influenced by other factors not included in the research model

\section{A. Indirect Effect}

The effect of work-life balance on (X) on performance (Y) with job satisfaction $(Z)$ as a mediating variable of:

Indirect effect $=\beta 1 \times \beta 3=0.983 \times 0.458=0.450$

\section{B. Total Effect}

The total effect of work life balance $(X)$ on performance $(\mathrm{Y})$ with job satisfaction $(\mathrm{Z})$ as an intermediary variable:

Total effect $=\beta 2+(\beta 1 \times \beta 3)=0.599+0.450=1.049$ 


\section{Sobel Test}

$$
\begin{gathered}
z=\frac{(0.983)(0.458)}{\sqrt{\left(0.458^{2} 0.55^{2}\right)+\left(0.983^{2} 0.189^{2}\right)+\left(0.115^{2} 0.189^{2}\right)}} \\
=2.316
\end{gathered}
$$

Based on the results of the Sobel test above, it shows that the tabulation $\mathrm{Z}=2.316>1.96$, which means that the job satisfaction variable significantly mediates the relationship between work-life balance and performance

\section{Discussion}

\section{1) Work-Life Balance on the Performance of Female Nurses}

The effect of work-life balance (X) on performance (Y) is 0.599 with a sig.t value comparison of 0.000 less than the significant value used $(0.000<0.05)$. This figure shows that work-life balance has a positive and significant effect on performance. This means that the better a person controls the balance between work and personal life, the better his performance when he is working. In this study, it can be explained that female nurses have implemented work-life balance well and are followed by their high performance.

\section{2) Effect of work-life balance on job satisfaction}

The effect of work-life balance (X) on job satisfaction (Z) is 0.983 with a sig.t value comparison of 0.000 less than the significant value used $(0.000<0.05)$. This figure shows that work-life balance has a positive and significant effect on job satisfaction. This means that someone who can maintain a good balance of work and personal life can produce satisfaction at work. In this study, it can be explained that female nurses have implemented work-life balance well and are followed by their high job satisfaction

\section{E. Job Satisfaction on the Performance of Female Nurses}

The effect of job satisfaction (Z) on performance (Y) is 0.458 with a comparison of the sig.t value of 0.000 less than the significant value used $(0.000<0.05)$. This figure shows that job satisfaction has a positive and significant effect on performance. This means that the higher the employee's job satisfaction, the employee's performance will also increase. In this study, it can be explained that female nurses have high job satisfaction and are followed by their high performance.

\section{F. Job Satisfaction mediates the effect of work-life balance on performance}

Based on the results of the Sobel test, the results of the tabulation $\mathrm{Z}=2.316>1.96$, which means that the job satisfaction variable significantly mediates the relationship between work-life balance and performance. This means that someone who can maintain a good balance between work and personal life can produce satisfaction at work so that employee performance will also increase. In this study it can be explained that female nurses have implemented work-life balance well, followed by their high satisfaction and performance

\section{G. Research Implication}

The theoretical implications of the results of this study provide evidence on the development of human resource management science that can explain the theoretical model used as a basis in formulating the hypothesis, namely the role of job satisfaction mediating the effect of work-life balance on the performance of female nurses who can empirically prove the theory used in This research is attribution theory and homeostasis. In his statement, attribution theory refers to how a person expresses the causes of the behavior of others or himself which is determined from internal (nature, character, attitude) and external (thoughts or certain circumstances that can influence individual behavior), while in the statement of homeostasis theory it is a form of human behavior who wants to find balance in himself. The results of the theoretical model explain that the factors that affect employee performance are job satisfaction through work-life balance. Therefore, with a better work-life balance, job satisfaction will increase and also increase the performance of female nurses. The results of these theoretical implications can also provide additional references for further research that discusses job satisfaction, work-life balance, and performance.

Practically it can be a reference for other researchers who want or are interested in researching work-life balance, job satisfaction, and performance. Theoretically, this study also provides an understanding that work-life balance and low job satisfaction can significantly reduce the performance of female nurses, when a good work-life balance is obtained from increased job satisfaction, the perceived job satisfaction becomes stronger so that it has the potential to improve the performance of female nurses. Therefore, the Head of the Nursing Service and the Head of the Sub-Division of Personnel at the Klungkung General Hospital can pay attention to these variables in making policies related to the performance of female nurses.

\section{H. Research Limitations}

The scope of the study only covers female nurses at the Klungkung General Hospital so it cannot describe the performance of all nurses or other health workers. Other variables can affect performance outside the model described in this study, such as professional commitment, motivation, organizational support, etc. This research is only carried out at a certain point in time (cross-section), while the environment changes at any time (dynamic), so this research is important to be carried out again in the future. There is a current pandemic, namely the Covid-19 pandemic which affects filling out questionnaires which takes a long time, which is caused by the female nurse at the Klungkung General Hospital having to finish her work first considering a large number of incoming patients.

\section{CONCLUSION}

Management should pay attention to the work-life balance of female nurses by being fair in determining the work schedules of nurses, making work schedules according to procedures, and not adding to the burden or working hours outside the agreed hours. Then for female nurses who are caring for or have children so that they can be more conditioned in determining the picket schedule on the night shift. Meanwhile, female nurses should be able to do good time management between work and personal life and not interfere with work problems with personal problems. Hospital management should be willing to provide seminars, training to add new insights for nurses, and need motivation, 
enthusiasm, and support from superiors so that the performance of female nurses can work as much as possible without the need for supervision and know how to treat patients who experience new diseases while working which will make nurses more confident in carrying out the work of the profession without any doubts and fears. To improve performance, it is necessary to have satisfaction obtained by female nurses, namely an increase in salary and special rewards that are proportional to the workload of nurses because at this time nurses who excel have not received special rewards, as well as for contract workers who have not received salaries according to the standards that have been set.

For future researchers, it is necessary to consider examining other variables, factors, and indicators outside of work-life balance and job satisfaction to determine performance. As well as being able to expand the scope of research not only female nurses. So that it provides a more comprehensive view and can be implemented in general.

\section{REFERENCES}

Darma, P. S., \& Supriyanto, A. S. (2017). The effect of compensation on satisfaction and employee performance. Management and Economics Journal (MEC-J), 1(1), 1.

Herlambang, H. C., \& Murniningsih, R. (2019). Pengaruh Worklife Balance Terhadap Kinerja Karyawan Dengan Kepuasan Kerja Sebagai Variabel Intervening (Studi Empiris pada Serikat Pekerja Media dan Industri Kreatif Untuk Demokrasi ). UMMagelang Conference Series, 558566.

Johari, J., Tan, F. Y., \& Zulkarnain, Z. I. T. (2018). Autonomy, workload, work-life balance and job performance among teachers. International Journal of Educational Management., 32(1), 107-120.

Juliarti, P. A. D., Agung, A. A. P., \& Sudja, I. N. (2018). Effect of Compensation and Work Environment on Employee Performance with Employee Job Satisfaction as an Intervening Variable. International Journal of Contemporary Research and Review, 9(3), 553-562.

Junaidin, Ikhram, A. A., \& Hardiyono. (2019). Pengaruh Work Life Balance Terhadap Burnout Dan Kepuasan Kerja Karyawan ( Studi Kasus Pada Perusahaan Listrik Negara ( PLN) Area Makassar Selatan ). MANDAR (Management Development and Applied Research Journal), 1(2), 27 34.

Kuranga, M. O., Mustapha, Y. I., \& Brimah, A. N. (2020). Impact Of Worklife Balance On Job Satisfaction Of Women Enterprenours In SouthWestern Nigeria. Fountain University Osogbo Journal Of Management, 5(1), 1-20.

Martono, S., Khoiruddin, M., \& Wulansari, N. A. (2018). Remuneration reward management system as a driven factor of employee performance. International Journal of Business \& Society, 19(1), 1.

Mendis, M. D. V. S., \& Weerakkody, W. A. S. (2017). The impact of work life balance on employee performance with reference to telecommunication industry in Sri Lanka: a mediation model. Kelaniya Journal of Human Resource Management, 12(1), 72-100.

Pawirosumarto, S., Sarjana, P. K., \& Gunawan, R. (2017). The effect of work environment, leadership style, and organizational culture towards job satisfaction and its implication towards employee performance in Parador Hotels and Resorts, Indonesia. International Journal of Law and Management, 59(6), $1337-1358$. https://doi.org/https://doi.org/10.1108/IJLMA-10-2016-0085.

Puspitasari, A. S. A., \& Darwin, M. (2021). Effect of Work-Life Balance and Welfare Level on Millennial Employee Performance Through Work Engagement. International Journal of Science and Society, 3(1), 334344.

Rafsanjani, F., Nursyamsi, I., \& Pono, M. (2019). The Effect of Work-Life Balance on Employee Performance with Job Stress and Job Satisfaction as Intervening Variables. Hasanuddin Journal of Business Strategy, 1(4), 37-42.

Ranjan, K. A., \& Khatke, A. (2021). Dimensions of Work Life Balance and its Impact on Job Satisfaction of Clinical Staff in Cancer Hospitals. International Journal of Research in Engineering, Science and Management, 4(6), 73-76.

Saifullah, F. (2020). Pengaruh Work-Life Balance dan Flexible Work Arrangement Terhadap Kinerja Karyawati Muslimah Konveksi.
BISNIS: Jurnal Bisnis Dan Manajemen Islam, 8(1), 29. https://doi.org/10.21043/bisnis.v8i1.6762.

Sambung, R. (2019). Job Satisfaction on Employee Performance; Counterproductive Work Behavior and Organizational Citizenship Behavior as Mediations. International Journal of Economic Behavior and Organization, 7(3), 50.

Saragih, E. H. (2021). Pengaruh Work Life Balance terhadap Kinerja Karyawan Generasi X dan Y di Jakarta. Journal of Emerging Business Management and Entrepreneurship Studies, 1(1), 1.

Suwandana, I. M. A., \& Perdanawati, L. P. V. I. (2020). The Role of Motivation on Performance with Job Satisfaction as a Mediation Variable. International Journal of Social Science and Business, 4(2), 430-436.

Usman, J., Sukmayuda, D. N., \& Kurniawati, S. (2019). Job satisfaction and employee performance shoes industry in Tangerang Regency Banten Province. International Review of Management and Marketing, 9(1), 98.

Wulandari, M., \& Hadi, H. K. (2021). Peran Job Satisfaction sebagai Variabel Intervening antara Work Life Balance terhadap Employee Performance. Jurnal Ilmu Manajemen, 9(2), 816. https://doi.org/10.26740/jim.v9n2.p816-829. 